\title{
Megapolitical CASEs before the CONSTITUTIONAL COURT OF INDONESIA SINCE 2004: AN EMPIRICAL STUDY
}

\author{
Björn Dressel $^{*}$ \\ Crawford School of Public Policy, Australian National University, Canberra, Australia \\ bjoern.dressel@anu.edu.au \\ Tomoo Inoue** \\ Seikei University, Tokyo, Japan \\ inoue@econ.seikei.ac.jp
}

\begin{abstract}
The Constitutional Court of Indonesia is considered one of Asia's most activist courts. Here we investigate empirically possible determinants of the decisions of its judges over the period 2003-18. The findings are based on a unique data set of 80 high-profile political cases, complemented by data on the socio-biographic profiles of 26 judges who served during that period. Testing for common perceptions of the Constitutional Court since its inception, we first describe patterns in judicial decision-making across time and court composition before testing specifically for the impact of the judges' professional backgrounds, presidential administrations, the influence of the Chief Justice, and cohort behaviour. The analysis finds declining dissent among justices on the bench over time and also provides evidence of strategic behaviour of justices at the ending of their own terms. But there is little statistical evidence that judicial behaviour has been affected by work background (except for those coming from the executive branch), appointment track or generation - hence suggesting that justices seem to retain more independence than the public seems to perceive. We then discuss the results in the context of Indonesia's evolving constitutional democracy and look at the implications for comparative studies of judicial behaviour.
\end{abstract}

Keywords: Constitutional Court, Judges, Judicial Behaviour, Indonesia, Megapolitical Cases

\footnotetext{
Associate Professor at the Crawford School of Public Policy, Australian National University, Australia.

** Professor of Economics at Seikei University, Tokyo, Japan.

The authors would like to thank academic participants of the Constitutional Court International Symposium (ICCIS) 2018 held in Yogyakarta 2-3 October 2018, where a preliminary draft of this paper was originally presented. Special thanks go to Estu Dyah Arifianti and Fakhridho SBP Susilo for excellent research assistance and Bisariyadi for continuous support throughout this project.
} 


\section{INTRODUCTION}

Courts have become major players in Asia's evolving political arenas. As countries in the region democratised and liberalised over the last 25 years, since the 1990s there has been growing judicial involvement and assertiveness in political matters. This has contributed to claims that in the region politics is becoming ever more judicialized, ${ }^{1}$ a trend that has been well-documented for some time in other parts of the world. ${ }^{2}$

The Constitutional Court of the Republic of Indonesia (Mahkamah Konstitusi, $\mathrm{MK}$ ) is a good illustration for this trend. In the past 15 years, the MK has revised seventy-four laws, annulled four completely, and nullified portions in the course of granting just over a quarter of all petitions. Perhaps more important, it has not shied away from political controversy; in fact some of its high-profile decisions are recognised as having had major political and economic repercussions; for instance it has invalidated the privatisation of electricity utilities; condemned government budgets that failed to allocate sufficient funds for education, and protected religious, ethnic and sexual minorities from government discrimination. ${ }^{3}$ Combined with its regular engagement in contested electoral matters, it is thus not surprising that the court is considered unusually activist. ${ }^{4}$

Such high-level engagement, although vulnerable to the dangers shown by the constitutional court in Thailand, ${ }^{5}$ seem to have done little to impugn the reputation of the Indonesian court. Much to the contrary, relying on its initial leadership and a 'built up stock of political capital because of its apparent integrity

\footnotetext{
Björn Dressel, The Judicialization of Politics in Asia (Abingdon and New York: Routledge, 2012).

Rachel Sieder, Line Schjolden, and Alan Angell, eds., The Judicialization of Politics in Latin America (New York and Houndsmills: Palgrave Macmillan, 2005); Neal C. Tate and Torbjörn Vallinder, eds., The Global Expansion of Judicial Power (New York: New York University Press, 1995).

3 Simon Butt, The Constitutional Court and Democracy in Indonesia (Leiden: Brill Nijhoff, 2015).

4 Dominic Nardi, "Demand-Side Constitutionalism: How Indonesian NGOs Set the Constitutional Court's Agenda and Inform the Justices" (Policy Paper., Centre for Indonesian Law, Islamic Society, 2018); Simon Butt, "Indonesia's Constitutional Court: A Reform Over-Achiever?," Inside Indonesia 87, no. July-September (2006).

5 Björn Dressel and Khemthong Tonsakulrungruang, "Coloured Judgement? The Work of the Thai Constitutional Court, 1998-2016,"Journal of Contemporary Asia early print (13 June 2018).
} 
and good faith'6 over the years, the court has experienced a 'remarkable rise'7 in public standing and found wide support in public opinion polls, despite a short, abrupt, but temporary drop in 2013 after its Chief Justice, Akil Mochtar, was arrested. ${ }^{8}$ As a result, together with the Corruption Eradication Commission (Komisi Pemberantasan Korupsi, KPK), it is one of the most respected institutions in the country ${ }^{9}$ - one that has been widely credited with helping the country's democratic consolidation. ${ }^{10}$

Yet more recent developments suggest that the court is confronted with growing problems and criticism. For instance, the arrests for corruption of Chief Justice Akil Mochtar in 2013 and Justice Patrialis Akbar in 2017 have raised questions about the MK's independence and evoked widespread public concerns that its judges are not immune from the endemic clientelist-corrupt practices in Indonesia's broader justice sector. ${ }^{.1}$ Civil society actors, meanwhile, have begun questioning the quality of appointments to the court, based on what is perceived to be an increasingly politicized appointment process, ${ }^{12}$ and academics have expressed concerns about a decline in leadership ${ }^{13}$ and the quality of decisions in terms of legal reasoning, consistency and the evidence base in high-profile cases. ${ }^{14}$ In general, then, the perception seems to be growing that

6 Donald Horowitz, Constitutional Change and Democracy in Indonesia (Cambridge and New York: Cambridge University Press, 2013): 243.

7 Theunis Roux and Fritz Edward Siregar, "Trajectories of Curial Power: The Rise, Fall and Partial Rehabilitation of the Indonesian Constitutional Court," Australian Journal of Asian Law 16, no. 2 (2016): 2.

8 An IFES poll in 2005 showed that 68\% approved the court (with $11 \%$ disapproving); a number that dropped to $28 \%$ when the Mochtar scandal broke (see, https://www.ifes.org/surveys/public-opinion-indonesia-2005). A 2018 LSI poll shows trust in the MK at 76\%, only surpassed by TNI (90.4\%); KPK (89\%); National Police (87\%) and BPK (79\%); see for results: https://nasional.kompas.com/read/2018/07/31/17242921/survei-Isi-dpr-lembaganegara-dengan-tingkat-kepercayaan-terendah.

9 See Kompas survey at: https://nasional.kompas.com/read/2017/10/21/07122651/survei-kompas-citra-tni-naikhingga-94-persen-citra-dpr-terendah.

10 Marcus Mietzner, "Political Conflict and Democratic Consolidation in Indonesia: The Role of the Constitutional Court," Journal of East Asian Studies 10, no. 3 (2010).

11 See "Judicial Mafia: Corruption as a barrier to justice in Indonesia", found at: https://www.ibj.org/2010/08/13/ judicial-mafia-corruption-as-a-barrier-to-justice-in-indonesia.

12 See, "Justice appointment 'a setback to democracy', Jakarta Post (July 31, 2013) at: http://www.thejakartapost. com/news/2013/07/31/justice-appointment-a-setback-democracy.html

${ }_{13}$ Stefanus Hendrianto, "The Rise and Fall of Heroic Chief Justices: Constitutional Politics and Judicial Leadership in Indonesia," Washington International Law Journal 25, no. 3 (2016).

14 Simon Butt, "Indonesian Constitutional Court decisions in regional head electoral disputes," (CDI Policy Papers on Political Governance., Australian National University, 2013), 1-37; Simon Butt, "The Constitutional Court's Decision in the Dispute Between The Supreme Court and the Judicial Commission: Banishing Judicial Accountability?," in Indonesia. Democracy and the Promise of Good Governance, ed. Ross H. McLeod and Andrew Maclntyre (Singa- 
Constitutional Court judges "are less competent, more partisan, and corrupt" in the words of a well-known observer during an international symposium. ${ }^{15}$

How well founded are these allegations? More specifically, what factors, other than the law, may influence the decisions of judges in high-profile cases? These questions are of particular relevance now: In 2019 another round of contested elections is likely to draw in the Constitutional Court. ${ }^{16}$

Answers to this question from scholars have been limited. While the MK has certainly garnered much attention in academic writing, there have been few studies from a positivist, empirical viewpoint. Instead, legal scholars have mainly described the MK's institutional powers and processes and the text of its decisions. ${ }^{17}$ Political scientists and socio-legal scholars have drawn attention to a variety of issues ranging from the foundation of the court; ${ }^{18}$ its role in democratic consolidation; ${ }^{19}$ the political environment, ${ }^{20}$ or aspects of court leadership. ${ }^{21}$ With only a few exceptions, ${ }^{22}$ studies of the MK generally make no appeal to hard quantitative evidence; most simply draw conclusions from a handful of selected cases, or apply only narrowly to specific issues, such as electoral law.

Unlike studies to date, then, we here apply an empirical methodology to the analysis of how the judges of the MK make decisions. The judicial behaviour at the Constitutional Court is explored using an original dataset we collected covering the period 2004-18 based on a stringent methodology for identifying

pore: Instititute of South East Asian Studies, 2007), 178-99; Stefanus Hendrianto, "The Indonesian Constitutional Court and the Crisis of the 2019 Presidential Election," I-CONnect Blog, no. Sept. 19, 2018 (2018).

15 Unassigned quote from Indonesia update, ANU Sept. 15, 2018 (correspondence on file with author).

16 Hendrianto, "The Indonesian Constitutional Court and the Crisis of the 2019 Presidential Election".

17 Butt, "Indonesian Constitutional Court decisions in regional head electoral disputes."; Stefanus Hendrianto, "Convergence or Borrowing: Standing in The Indonesian Constitutional Court," Constitutional Review 1, no. 1 (2015).

18 Petra Stockmann, The New Indonesian Constitutional Court: A Study Into its Begining and First Years of Work (Jakarta: Hanns Seidel Foundation, 2007). Hendrianto, "Institutional Choice and the New Indonesian Constitutional Court," in New Courts in Asia, ed. Andrew Harding and Penelope Nicholson (Oxon and New York: Routledge, 2010), 158-77.

19 Mietzner, "Political Conflict and Democratic Consolidation in Indonesia: The Role of the Constitutional Court."

20 Fritz Siregar, "The Political Context of Judicial Review in Indonesia," Indonesia Law Review 2(2015).

21 Stefanus Hendrianto, Law and Politics of Constitutional Courts: Indonesia and the Search for Judicial Heroes (New York: Routledge, 2018).

22 Dominic Nardi, "Demand-Side Constitutionalism: How Indonesian NGOs Set the Constitutional Court's Agenda and Inform the Justices," CILIS Policy Papers (Melbourne 2018). 
megapolitical cases. We complement this dataset of 80 cases with sociobiographic profiles of the 26 judges who served on the MK bench during this period. Patterns of judicial alignment and dissent are tested using the original dataset to explore the extent to which the court plays a counter-majoritarian role in Indonesia's political system.

Our systematic analysis of descriptive data and the results of the regression analysis fail to support the claim that $\mathrm{MK}$ is politicized and thus lacks independence - measured narrowly here in terms of votes for and against the sitting government. ${ }^{23}$ While it is true that over time there has been a decline in dissent on the bench, we found no statistical evidence that traits such as work background, paths to appointment, or cohort behaviour, influenced MK decisions for or against the government in high-profile cases. The results are thus somewhat surprising given the wave of recent pessimism about the MK's judicial behaviour. And although we do not in any way suggest that our findings can be read without deep consideration of the context and content of each decisions, we do expect our study to help forward a much-needed better understanding of the behaviour of MK judges by providing the first systematic account of their decision making - one that is more positive than standard accounts in current scholarship.

The paper is structured as follows: To fully appreciate how MK judges behave, in Section I, we address the MK's institutional background and performance. Section II briefly summarises theories of judicial behaviour and the initial hypothesis, followed by discussion of the empirical results in Section III. Section IV sets out final conclusions.

\footnotetext{
${ }_{23}$ There is a large and complex literature on judicial independence (e.g., Julio Rios-Figuero and Jeffrey K. Staton, "An Evaluation of Cross-National Measures of Judicial Independence," The Journal of Law, Economics, and Organizations 30, no. 1 (2009); Peter H. Russel, "Towards a General Theory of Judicial Independence," in Judicial Independence in the Age of Democracy. Critical Perspectives from around the World, ed. Peter H. Russel and David M O'Brian (Charlottsville and London: University of Virginia Press, 2001). For the approach chosen here see, Desiree A. Desierto, "Judicial Independence: Evidence from the Philippine Supreme Court (1970-2003)," in The Political Economy of Governance, ed. Norman Schofield and Gonzalo Caballero (Cham: Springer International Publishing, 2015), 41-57.
} 


\section{Establishment, Powers and Performance of the The Constitutional Court of the Republic of Indonesia}

The Constitutional Court of the Republic of Indonesia (Mahkamah Konstitusi, MK) was established by statute in August 2003;24 the idea had been discussed in a working committee of the People's Consultative Assembly (Majelis Permusyaratn Rakyat, MPR) and was revived and brought to fruition during Indonesia's prolonged process of constitutional amendment process (1999-2004). Given a sense of urgency caused by the constitutional crisis triggered in 2001 by the impeachment process against then-president Abdurrahman Wahid (1999-2001), and despite considerable resistance from political and some legal actors (among them the Supreme Court), the Constitutional Court was seen as a way to fill a judicial gap that had caused legal uncertainty and prolonged political disputes since independence in $1945 .{ }^{25}$

The Constitutional Court Act gave the MK five specific mandates: judicial review of legislation for adherence to the constitution; resolving disputes about the relative jurisdiction of state institutions; dissolving political parties; hearing electoral disputes (Art. $24 \mathrm{C}(1)$ ), and deciding on motions to impeach the president or vice president (Art $24 \mathrm{C}(2))$. Later laws to curtail some of these powers have not only been rejected by the MK but also countered by its broad interpretation of its powers, ${ }^{26}$ which led some observers to wonder if the court had morphed from the envisioned 'negative' legislator to a 'positive' legislator despite attempts at self-restraint (e.g., review limited to norms, prospectivity). ${ }^{27}$

Safeguards for judicial independence are strong - at least formally. The law provides for both a multiple-track appointment system and budget autonomy.

\footnotetext{
24 The Court's governing law, the 2003 Constitutional Law, was passed on 13 August 2003. Provisions had been made for the Court's establishment in the third amendment to Indonesia's Constitution, approved on 9 November 2001, and the fourth amendment (10 August 2002).

25 Butt, The Constitutional Court and Democracy in Indonesia: 9-32; Stockmann, The New Indonesian Constitutional Court: A Study Into its Begining and First Years of Work.

26 See Constitutional Court Decision 066/PUU-II/2004 [Chamber of Industry Case (2004)]; for historical account of the debates on Art. 50 of the Constitutional Court Law, see Butt 2013: 90-91

27 Simon Butt, "Indonesia's Constitutional Court: Conservative Activist or Strategic Operator?," in The Judicialization of Politics in Asia, ed. Björn Dressel (Abingdon; New York: Routledge, 2012).
} 
Of the nine Constitutional Court Judges, who serve five-year terms, renewable once, and have to retire at 70 (67 until 2011), three a nominated by the president, three by the legislature, and three by the Supreme Court. Modelled after appointment to the South Korean Constitutional Court, ${ }^{28}$ this mechanism aims to prevent a single institution from monopolizing the court and seeks a healthy balance between executive, legislative, and judicial appointments. Judges who seek renewal of their terms may explore all three avenues, reducing their dependence on the institution that initially nominated them. ${ }^{29}$ Similarly, full budget autonomy is meant to insulate the institution and its judges from Indonesia's notorious political and judicial corruption..$^{30}$

However, concerns about the inner working of the court in light of alleged ethics violations and widely publicized corruption cases have prompted changes to the 2003 Constitutional Court Law. In 2011 the Indonesian parliament changed the arrangements for the Court's ethics council, strengthening the qualifications and experience required for appointment of justices (already high with the requirement of a $\mathrm{PhD}$ ); a reduction in the term of the court chair (akin to Chief Justice) and deputy chair from three to two and a half years, and in October 2013, following the arrest of Akil Mochtar, Indonesian president Yudhoyono issued a regulation-in-lieu-of-law (known as a Peraturan Pemerintah Pengganti Undang-undang or Perpu) that would require justices to have had no links to a political party for seven years and to undergo screening by an independent selection panel..$^{31}$ However, in 2014 the court rejected this Perpu in its entirety..$^{32}$

The court has had a high workload for the last 15 years. This is because the number of cases filed has gradually increased, with considerable spikes during election times when the court has to deal with large amounts of disputes related to local as well as presidential and legislative elections (see figure 1).

\footnotetext{
${ }_{28}$ Hendrianto, "Institutional Choice and the New Indonesian Constitutional Court," 161.

29 So far, only two judges have made use of this option (i.e., Harjono and Palguna).

$3^{\circ}$ Daniel S. Lev, "State and Law Reform in Indonesia," in Law Reform in Developing and Transitional States, ed. Timothy Lindsey (London and New York: Routledge, 2007).

${ }^{1}$ Haeril Halim and Ina Parlina, 'House endorses SBY's MK reform plan', The Jakarta Post, 20 December 2013

32 Constitutional Court Decision 1-2/PUU-XII/2014.
} 


\section{Figure 1: Constitutional Court Case Petitions by Type, 2003-17}

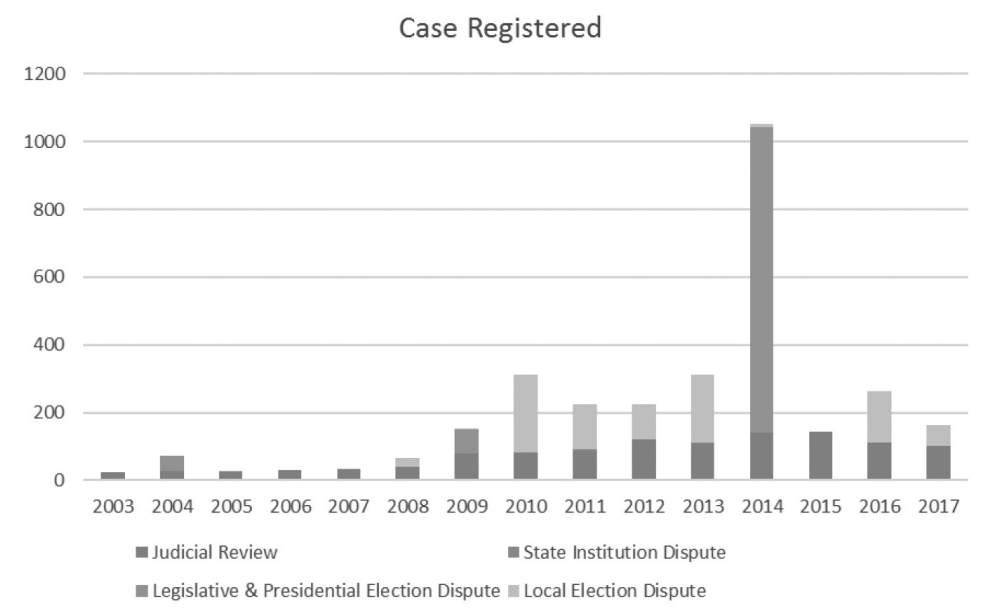

Source: MK.

Judicial review cases also steadily increased, though they have plateaued over the last five years. On average, about 25 percent of these petitions are granted; on average the court has rejected outright more than a third of the petitions - a trend that has been rising in the last five years, together with some applications becoming 'non-acceptable' (figure 2).

Figure 2: Judicial Review Decisions by Category, 2003-17

Judicial Review Decisions

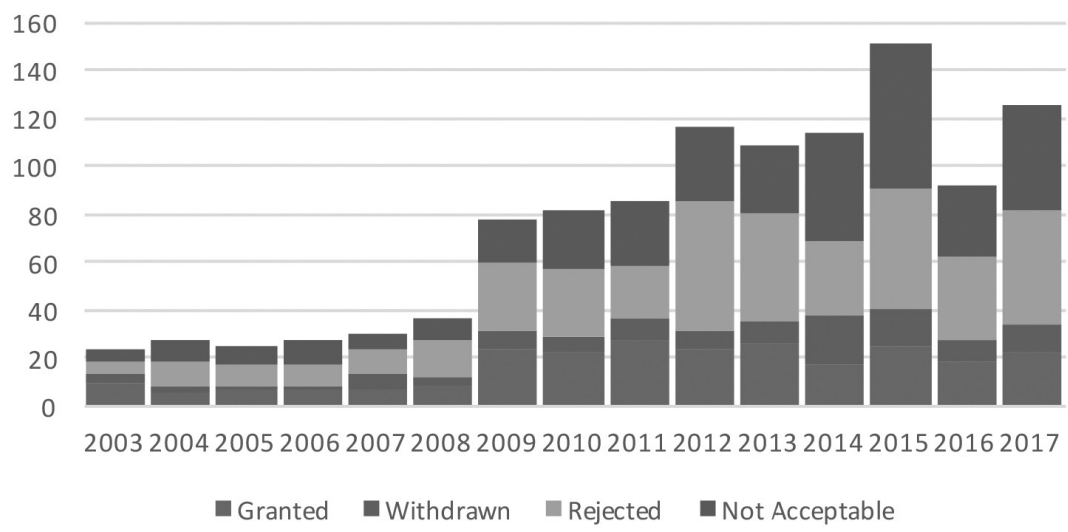

Source: MK. 
While the court is understood to have maintained high standards under high workload, ${ }^{33}$ it has also faced growing criticism. Perhaps because of the high case load, some observers have noted that debate among justices is declining in high-profile cases and even suggested that as a result rulings are shorter. ${ }^{34}$ Cases of corruption by justices on the bench (e.g., CJ Mochtar in 2013 and Patrialis Akbar in 2017) have also intensified public concerns about whether the bench is independent of political and business interests, ${ }^{35}$ if not the 'quality' of its justices over time. Some authors have suggested qualitative differences between the 'generations' of justices on the bench, ${ }^{36}$ and a decline in court leadership, ${ }^{37}$ both stemming from a more politicized appointment process despite new regulations..$^{8}$ Others have suggested that court decisions are largely driven by public opinion, particularly in highprofile political cases, and there is some empirical evidence of that. ${ }^{39}$

Taken together, these suggestions ultimately reveal concerns about what is driving the behaviour of judges on one of Asia's most activist courts: How do Constitutional Court justices make decisions, particularly in cases where political influence is likely to be exerted on them. Keeping such perceptions in mind, the next section will briefly review some current theories about judicial behaviour, before we test assumptions empirically.

\section{Theory and Hypothesis}

Judicial decision-making in high courts, whether supreme or constitutional courts, is a result of multiple variables. Personal attributes and attitudes matter (including policy preferences, for example, dispositions about outcomes and policies). Intra-court interaction also matters (natural pressure for consensus;

33 Butt, The Constitutional Court and Democracy in Indonesia: 6

34 Butt, The Constitutional Court and Democracy in Indonesia: 62.

35 See, Is the Indonesian Constitutional Court Corrupt?, Leiden Law Blog, https://leidenlawblog.nl/articles/is-theindonesian-constitutional-court-corrupt.

${ }^{36}$ Hendrianto, "The Rise and Fall of Heroic Chief Justices: Constitutional Politics and Judicial Leadership in Indonesia."

37 Stefanus Hendrianto, Law and Politics of Constitutional Courts: Indonesia and the Search for Judicial Heroes.

${ }^{8}$ Pan Mohamad Faiz, "A Critical Analysis of Judicial Appointment Process and Tenure of Constitutional Justice in Indonesia," Hasanuddin Law Review 2, no. 2 (2016): 152-68.

39 Nardi, "Demand-Side Constitutionalism: How Indonesian NGOs Set the Constitutional Court's Agenda and Inform the Justices." 
concern for court reputation; a common objective to empower the court over competing political and judicial actors). Party politics may also be relevant (for example, loyalty to the appointer). Finally, these variables interact in a specific constitutional and doctrinal environment, some with more, others with less legal formalism.

The relative importance of these variables varies with explanatory theory. $4^{40}$ For instance, the legal model assumes that judges decide in conformity with laws and precedent. ${ }^{41}$ Fostering an image of judges as neutral and apolitical, they use technical interpretation skills to ascertain the law that best applies to the specific case. ${ }^{42}$ Other approaches portray judges as individuals with discernible political motivations-attitudinal models argue that ideological positions and policy preferences shape judicial decisions, especially in courts of last resort.43 They downplay the influence of law and portray judges as focused on legal policy. ${ }^{44}$ The strategic model of judicial decision-making, also guided by the notion of judicial policy preferences, acknowledges that judges take into account the views of other actors and the institutional context, and may even deviate from a preferred outcome to take those views into account. ${ }^{45}$

A full discussion of these theories is beyond the scope of this paper. Suffice it to say that recent academic debates have increasingly raised concerns about the reach of certain models beyond the West. ${ }^{46}$ Legal, attitudinal, and strategic

40 See a good overview in Lawrence Baum, Judges and Their Audiences: A Perspective on Judicial Behavior (Princeton: Princeton University Press, 2006), 1-21; Theunis Roux, The Politico-Legal Dynamics of Judicial Review: A Comparative Analysis, Comparative Constitutional Law and Policy (Cambridge: Cambridge University Press, 2018).

${ }_{41}$ Michael A. Bailey and Forrest Maltzman, The Constrained Court: Law, Politics and the Decisions Justices Make (Princeton: Princeton University Press, 2011).

42 Martin Shapiro, Courts: A Comparative and Political Analysis (Chicago: Chicago University Press, 1981).

43 Jeffrey A. Segal and Harold J. Spaeth, The Supreme Court and the Attitudinal Model (New York: Cambridge University Press, 1993); Jeffrey Segal, The Supreme Court and the Attitudinal Model Revisited (Cambridge: Cambridge University Press, 2002).

44 Lawrence Baum, "What Judges: Judges' Goals and Judicial Behavior," Political Research Quarterly 47, no. 3 (1994): 749-68.

45 Lee Epstein and Jack Knight, The Choices Justices Make (Washington, DC: CQ Press, 1998); Mark J. Ramseyer, "The Puzzling (In)Dependence of Courts: A Comparative Approach," Journal of Legal Studies 23(1994); Pablo Spiller and Rafael Gely, "Strategic Judicial Decision-making," in The Oxford Handbook of Law and Politics, ed. Keith E. Whittington, Daniel R. Kelemen, and Gregory A. Caldeira (Oxford: Oxford University Press, 2010).

46 Theunis Roux, "American Ideas Abroad: Comparatiove Implications of US Supreme Court Decision-Making Models," I Con 13, no. 1 (2015); Björn Dressel, Raul Sanchez Urribarri, and Alexander Stroh, "Courts and Informal Networks: Towards a Relational Perspective on Judicial Politics beyond Western Democracies," International Political Science Review 39, no.5 (2018): 573-584. 
accounts tend to assume that political institutions and legal systems are solidly institutionalized-hardly the case in the Global South. They also tend to portray judges as insulated conflict adjudicators, motivated by individual preferences and engaging with other legal and political actors solely to advance their own goals. Yet the motivations of judicial behaviour are complex; often they are not based on ideological fault-lines, particularly in settings best described as clientelist, weakly institutionalized, and highly relational. ${ }^{47}$ As a consequence, in such settings, the interplay between law and politics attracts more attention..$^{8}$

The model we propose here is loosely inspired by the strategic model identifiable in the literature. ${ }^{49} \mathrm{We}$ first explore and then, in line with the model, test some of the broader perceptions of the behaviour of Constitutional Court judges. Hence, we start by presenting basic statistics describing the background of judges and the composition of the bench, before testing specifically for the effects of the presidential administration; the work background of judges; and the generational cohort. We also control for age, gender and decision tendency over time. In other words, we do not assume that ideological preferences, which in the Indonesian political context are hard to discern, affect decisions for or against the government in high- profile cases, but rather that the dynamics might be driven by personal traits such as work background, appointments, and generational cohort - broadly in line with the strategic model.

Recognizing the widespread public perceptions and criticisms of the court, we test for five different sub-hypotheses broadly in line with a strategic understanding of the behaviour of the MK justices:

(H1) While the appointer is in office, the justices are loyal to the President for reasons loosely similar to those of the attitudinal or strategic model. However, once the presidential term is nearing completion, strategic

47 Björn Dressel, "The Informal Dimension of Judicial Politics: A Relational Perspective," Annual Review of Law and Social Science 13 (2017): 413-30.

48 Roux, The Politico-Legal Dynamics of Judicial Review: A Comparative Analysis.

49 The attitudinal model, which assumes that judicial behaviour takes the form of sincere ideological voting due to the combination of life tenure, no judicial superiors, docket control, and no career ambition, seems ill-adapted to the MK bench given mandatory retirement age, limited docket control, renewed appointments and post-judicial career trajectories. 
defection is likely, thus increasing the likelihood of a vote against the presidential administration.

$\left(\mathrm{H}_{2}\right)$ The closer justices are to retirement age, or the closer the end of the president's term, the more likely justices are to vote against the current administration for reasons similar to those of the strategic model.

(H3) There are distinct differences in behaviour between the various generations of MK judges. Compared to the first generation of justices (the first 9 appointees), subsequent generations are less likely to vote against the government.

$\left(\mathrm{H}_{4}\right)$ The previous work background of justices matters. Compared to career justices, in high-profile cases those who have worked in the executive or legislative branch are more likely to vote pro-government, while scholars are more likely to vote anti-administration.

Members and Decisions of the Constitutional Court. As the hypotheses make clear, many perceptions of the court have emerged over the years. We start testing some of the assumptions by first (a) providing descriptive statistics on the court bench and its members, and then (b) looking more closely at individual voting behaviour of justices, including some inferential statistics on how certain traits may account for their individual voting behaviour in the sample of political cases.

\section{DATA SET AND METHODS}

We analysed and coded 80 decisions issued by the Constitutional Court of Indonesia from 2004 to 2018 (see Appendix). As explained earlier, we included only cases that are (mega)political, chosen based on (1) coverage on the front page of two major newspapers; (2) citations in publications about the MK; and (3) vetting by local experts. Megapolitical cases are of particular interest here because we expect personal and political factors to become particularly important to decision making due to the nature of the issues and the weaker doctrinal basis for decisions in these matters. 
The individual votes of each justice in the 80 cases give us 710 observations. The outcome of interest, the dependent variable in the regression analysis, is a vote against the administration in power. We also amassed socio-biographic data for the 26 judges who voted in these cases, such as time on the bench, university affiliation and year of graduation, and professional career and workplace before appointment.

\section{FINDINGS}

\subsection{The Bench}

The sample period, 2004-18, coincides with the administrations of presidents Megawati (2001-04); Susilo Bambang Yudhoyono (SBY; 2004-14) and Joko Widodo (2014-present). Within this period, 26 justices were appointed and 10 reappointed: 9 under Megawati, 20 under SBY and 7 under Joko Widodo (see Table 1).

Table 1: Demographic Profiles of Who Sits on the Bench

\begin{tabular}{|l|l|c|c|c|}
\hline \multicolumn{2}{|c|}{} & Megawati & Yudhoyono & Widodo \\
\hline \multicolumn{2}{|c|}{ No. of Appointments } & 9 & 20 & 7 \\
\hline Gender & Male & $100 \%$ & $90 \%$ & $86 \%$ \\
\hline & Femaleo & $0 \%$ & $10 \%$ & $14 \%$ \\
\hline & UI & $22 \%$ & $20 \%$ & $0 \%$ \\
\hline & Hasanuddin U & $11 \%$ & $25 \%$ & $0 \%$ \\
\hline & Islam Indonesia & $0 \%$ & $5 \%$ & $14 \%$ \\
\hline & Gadjah Mada & $11 \%$ & $5 \%$ & $14 \%$ \\
\hline & Udayana U & $11 \%$ & $0 \%$ & $14 \%$ \\
\hline & Other & $44 \%$ & $45 \%$ & $57 \%$ \\
\hline & Prior Position & $33 \%$ & $30 \%$ & $43 \%$ \\
\hline & Acadicial & $11 \%$ & $25 \%$ & $29 \%$ \\
\hline & Executive & $33 \%$ & $20 \%$ & $29 \%$ \\
\hline & Parliament & $22 \%$ & $25 \%$ & $0 \%$ \\
\hline & Java & $44 \%$ & $40 \%$ & $29 \%$ \\
\hline & Sumatra & $33 \%$ & $20 \%$ & $43 \%$ \\
\hline & Kalimantan & $0 \%$ & $10 \%$ & $0 \%$ \\
\hline & Sulawesi & $11 \%$ & $20 \%$ & $0 \%$ \\
\hline & Nusa Tenggara & $11 \%$ & $10 \%$ & $29 \%$ \\
\hline
\end{tabular}

Source: compilation by authors from MK and public records 
With the exception of gender, these justices are quite diverse, perhaps reinforced by the mixed appointment process. No university dominates appointments to the bench. In fact, only the University of Indonesia and University of Hasanuddin have ever managed to have two or three graduates on the bench simultaneously, and only for a small number of cases. Other popular universities are the University of Airlangga, University of Islam Indonesia and University of Udayana. Justices from Java and Sumatra are the principal groups on the MK, which makes Sumatra over-represented relative to population distribution (Table 1 ).

During the sample period, a third of MK positions were consistently assigned to career justices, consistent with the nomination pathway from the Supreme Court. Justices with experience in the executive branch before ascending to the bench are the second largest group (though this group fell to zero in the middle of the sample period). Justices with a legislative background reached a maximum of seven, though currently none is on the bench. Interestingly, throughout the same period there is always at least one MK justice with a scholarly background (perhaps a minor consequence of the PhD requirement), and scholars seem to be equally likely to have been nominated by parliament or the president. By contrast, there seems to be a slight preference for presidential appointees to themselves come from the executive office. Only two of the justices reappointed were nominated by two different institutions (see Table 2 ).

Table 2: Work Background of Justices by Appointing Institution

\begin{tabular}{|c|c|c|c|c|c|c|}
\hline & \multicolumn{4}{|c|}{ Job Prior Appointment } & \multirow[b]{2}{*}{ Total } \\
\hline & & Executive & Judiciary & Parliamentary & Scholar & \\
\hline \multirow{3}{*}{$\begin{array}{l}\text { Appointed } \\
\text { Institution }\end{array}$} & Parliament & 3 & o & 5 & 4 & 12 \\
\hline & \begin{tabular}{|l|} 
President \\
\end{tabular} & 6 & 0 & 2 & 4 & 12 \\
\hline & Supreme Court & $\mathrm{O}$ & 12 & 0 & 0 & 12 \\
\hline & Total & 9 & 12 & 7 & 8 & 36 \\
\hline
\end{tabular}

Note: A justice who served two terms may be appointed by the same institution or by different institutions. Therefore, we counted the number of combinations for each term. 10 justices served two terms either continuously or after a break, and 15 justices served one term. 
Table 3: Reasons for Leaving the Bench

\begin{tabular}{|c|c|c|}
\hline Reason for End of Tenure & Total Number & Percentage (\%) \\
\hline Retirement & 7 & 41 \\
\hline Resignation & 2 & 12 \\
\hline One Term Only & 3 & 18 \\
\hline Two Term Limit & 3 & 18 \\
\hline Dismissed & 2 & 12 \\
\hline Sum & 17 & 100 \\
\hline
\end{tabular}

Combined, our data reveals a highly diverse (notably except for gender) $)^{50}$ and a relative stable bench over the sample period. Unlike other high courts in the region (e.g., Thailand, Philippines, Malaysia), appointments to the bench are not dominated by certain universities, nor is the pathway limited to certain work backgrounds (e.g., career judiciary). Much of this may be a direct result of the mixed appointment process that - although it may be increasingly politicized - has also allowed for a diverse group of judges who meet the vetting process and selection criteria to be appointed.

\subsection{Voting Patterns, 2004-18}

The number of megapolitical cases rose gradually over time, except for surges in 2008 and 2014 due to elections. This is also reflected in the distribution of cases by category; almost a third of cases dealt with electoral disputes (28\%) and slightly more with rights and civil liberties (33\%); the rest related to separation of powers $(24 \%)$, economics $(9 \%)$ and executive prerogatives (6\%). Although 39 cases $(49 \%)$ had at least one dissenter, the remaining 41 were decided unanimously $(51 \%)$.

Only 80 cases (of a total sample of 89) were considered relevant to this study. Of these, the Constitutional Court decided almost $75 \%$ against and only $25 \%$ for the sitting government. In cases involving separation of

50 Recent appointment of Justice Enny Nurbaningsih by president Joko Widodo as replacement for retiring justice Maria Farida Indrati from a female-only shortlist of candidates might be seen as a growing awareness of gender imbalance on the bench. 
powers (80\%) and executive prerogatives (80\%) the court voted most often against the government; the majority of cases dealing with economic issues were decided $(57 \%)$ for the government.

Overall, the MK granted $83 \%$ of the petitions in our sample. This number is significantly higher than the total of petitions received during this period (e.g., roughly a quarter), but this might also be because since 2005 the Court has granted a growing number of petitions only partially, as part of its rulings of cases as 'conditionally' unconstitutional (48\% of the petitions granted in our sample). This tendency has increased over time, and become particularly pronounced under Chief Justice Arief Hidayat: of 23 decisions during his tenure, 15 were judged conditionally (un)constitutional (see Table 4$) \cdot{ }^{51}$

Table 4: Case Outcomes by Chief Justice

\begin{tabular}{|c|c|c|c|c|c|}
\hline & $\begin{array}{c}\text { Granted } \\
\text { (Fully) }\end{array}$ & $\begin{array}{c}\text { Granted } \\
\text { (Partially) }\end{array}$ & Rejected & Not Accepted & Total \\
\hline Jimly Asshiddiqie & 13 & 1 & 3 & 1 & 18 \\
\hline Moh. Mahfud MD & 17 & 8 & 4 & 0 & 29 \\
\hline Akil Mochtar & 1 & 3 & 0 & 0 & 4 \\
\hline Hamdan Zoelva & 1 & 4 & 0 & 0 & 5 \\
\hline Arief Hidayat & 2 & 15 & 4 & 2 & 23 \\
\hline Anwar Usman & 0 & 1 & 0 & 0 & 1 \\
\hline Total & 34 & 32 & 11 & 3 & 80 \\
\hline
\end{tabular}

As for the average dissent rate of the bench - here defined as the number of anti-administration votes over total votes - there are two peaks, one in the first third of the sample, and the other in the last third. In fact, early in the sample period, anti-administration votes reached $80 \%$, but gradually dropped to 55\%; it then rose about 90\% in 2012 before easing to about 50\% in 2018. Overall, anti-administration rates differed depending on who was president. During the last third of the sample, the rates declined gradually, perhaps because doctrinal positions were more established.

${ }^{1}$ See good overview, Bisariyadi, "A Typical Rulings of The Indonesian Constitutional Court," Hasanuddin Law Review 2, no. 2 (2016): 225-40; Bisariyadi, "The Application of Legal Construction in the Rulings of the Constitutional Court," MIMBAR HUKUM 29, no. 1 (2017): 135-49. 
Table 5: Dissent Rate by President

\begin{tabular}{|l|c|c|}
\hline & Dissent Rate & No. of Cases \\
\hline Megawati Soekarnoputri & $44 \%$ & 2 \\
\hline Susilo Bambang Yudhoyono (1) & $68 \%$ & 26 \\
\hline Susilo Bambang Yudhoyono (2) & $86 \%$ & 28 \\
\hline Joko Widodo & $54 \%$ & 24 \\
\hline
\end{tabular}

Note: Note: Average dissent rates for the bench are calculated by taking a simple average of case-specific dissent rates. Dissent rate takes one when justices voted against the administration in power unanimously; zero when justices voted for the administration unanimously.

Equally interesting is the fact that the dispersion of decisions among MK justices as measured by standard deviation declined over the sample period and decisions have become increasingly unanimous (Figure 3).

\section{Figure 3: Dispersion of Decisions on the Bench}

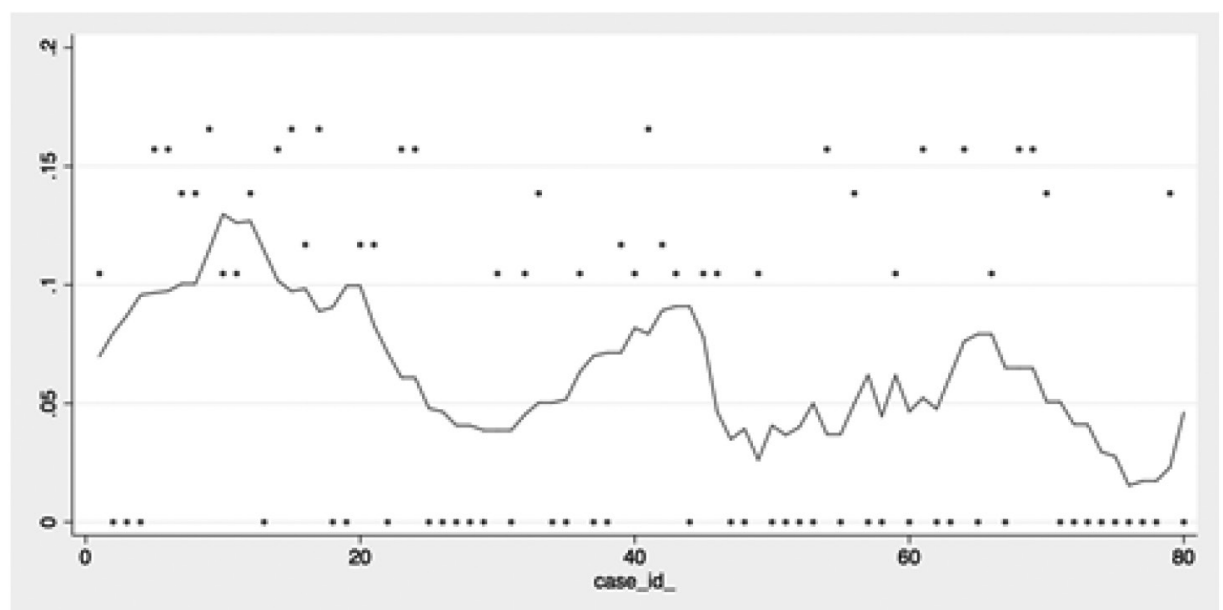

Note: A standard deviation of votes by bench is used as a measure of dispersion. The red line is calculated by taking 11-case centered moving average of dispersion by case.

In short, while there is little ground to suggest that the court has become more likely to vote for the government (as it is sometimes suggested in public discourse), it is certainly true that there is less disagreement 
among the justices. This is particularly true since 2014 with Joko Widodo as president (last 24 cases). There are also sharp differences in dissents under CJ Hamdan Zoelva and CJ Arief Hidayat, which might perhaps suggest the CJ has a subtle influence on the voting patterns of MK (though short CJ tenures also limit that).

\subsection{Individual Voting and Regression Findings}

What about behavioural differences between individual justices? A closer look at their voting records reveals sharp differences in votes for and against the government (see Table 6). For instance, in the sample of high profile cases considered here Justices I Dewa Gede Palguna, Ahmad Syarifuddin Natabaya and Suhartoyo voted for the sitting administration more than $50 \%$ of the time. By contrast, five justices-Ahmad Fadlil Sumadi, Hamdan Zoelva, Muhammad Alim, Moh. Mahfud MD, and Saldi Isra-voted against the government more than $80 \%$ of the time.

Table 6: Top 5 Voters for and against the Sitting Administration

\begin{tabular}{|l|l|l|l|l|l|}
\hline \multicolumn{2}{|c|}{ Top Voters For Government } & $\%$ & \multicolumn{2}{l|}{ Top Voters Against Government } & $\%$ \\
\hline$(1)$ & I Dewa Gede Palguna (E) & 59 & $(1)$ & Ahmad Fadlil Sumadi (J) & 83 \\
\hline$(2)$ & Ahmad Syarifuddin Natabaya (E) & 56 & $(2)$ & Hamdan Zoelva (P) & 83 \\
\hline$(3)$ & Suhartoyo (J) & 52 & $(3)$ & Muhammad Alim (J) & 82 \\
\hline$(4)$ & Manahan M.P. Sitompul (J) & 47 & $(4)$ & Moh. Mahfud MD (P) & 81 \\
\hline$(5)$ & Achmad Roestandi (P) & 44 & $(5)$ & Saldi Isra (S) & 80 \\
\hline
\end{tabular}

Note: Letters in brackets indicate the professional affiliation of judges immediately before nomination to the MK bench: P-Parliament; E-Executive; J-Judiciary; S-Scholar

Similarly, there are considerable differences between justices in their willingness to dissent from the majority opinion. For instance, Justice Achmad Roestandi dissented in half of the cases he was involved in, and Justices I Dewa Gede Palguna and Ahmad Syarifuddin Natabaya did so in almost a third of their cases. Perhaps even more interesting is that Justices Hamdan Zoelva and Jimly Asshiddiqie never dissented from the majority, closely 
followed by Justices Anwar Usman, Muhammad Alim, and Arief Hidayat (Table 7). That four of these five were also $\mathrm{CJ}$ during their tenure suggests that Chief Justices have an important role in marshalling these majorities.

Table 7: Top 5 Dissenting and Non-Dissenting Justices

\begin{tabular}{|l|l|c|c|l|l|l|}
\hline \multicolumn{2}{|c|}{ Top Dissenters on the Bench } & $\%$ & \multicolumn{2}{|c|}{ Top Non-Dissenters on the Bench } & $\%$ \\
\hline$(1)$ & Achmad Roestandi (P) & 59 & $(1)$ & Hamdan Zoelva (P, CJ) & 83 \\
\hline$(2)$ & Ahmad Syarifuddin Natabaya (E) & 56 & $(2)$ & Jimly Asshiddiqie (S,CJ) & 83 \\
\hline$(3)$ & I Dewa Gede Palguna (E) & 52 & $(3)$ & Anwar Usman (J, CJ) & 82 \\
\hline$(4)$ & Suhartoyo (J) & 47 & $(4)$ & Muhammad Alim (J) & 81 \\
\hline$(5)$ & Saldi Isra (S) & 44 & $(5)$ & Arief Hidayat (S,CJ) & 80 \\
\hline
\end{tabular}

Note: Letters in brackets indicate the professional affiliation of judges immediately prior to the nomination to the MK bench: P-Parliament; E-Executive; J-Judiciary; S-Scholar. CJ stands for Chief Justice.

Such differences then raise a broad question: do individual traits shape the voting patterns of MK justices? In other words, can we associate the variation of voting behaviour with the character of justices?

To find out we engage in some basic inferential statistics. Our dependent variable is binary, with a value of one if the vote is against the administration in power or zero if not. Independent variables are:

- Tenure remaining_as_President: the number of years left for the current president, assuming two terms for SBY and Jokowi .

- Tenure remaining_as_Justice: the remaining number of years as justice.

- Appointing institution dummy variables: setting the Supreme Court as a benchmark.

- Job prior to appointment dummy variables: setting judiciary background as a benchmark.

- Chief Justice dummy variables: setting the period of CJ Asshiddiqie as a benchmark.

- Generation dummy variable: setting the justices in the first generation as a benchmark. 
Since we draw on 710 votes by the 26 justices in 80 cases from 2004 to 2018 , the panel data structure is highly unbalanced; the votes of individual justices ranged from 5 to 61 , and the average was 28.4 votes. We therefore fitted a random effects Probit model and estimated the parameters by maximum likelihood. The results are presented in Table 8 .

Table 8: Regression Results

\begin{tabular}{|c|c|c|c|c|}
\hline & Model-1 & Model-2 & Model-3 & Model-4 \\
\hline Remaining_Tenure_of_President & $\begin{array}{c}-0.112^{* * *} \\
{[0.017]}\end{array}$ & $\begin{array}{c}-0.105^{* * *} \\
{[0.018]}\end{array}$ & $\begin{array}{l}-0.029 \\
{[0.030]}\end{array}$ & $\begin{array}{c}-0.103^{* * *} \\
{[0.018]}\end{array}$ \\
\hline Remaining_Tenure_as_Justice & $\begin{array}{c}-0.084^{* *} \\
{[0.035]}\end{array}$ & $\begin{array}{c}-0.090^{* * *} \\
{[0.035]}\end{array}$ & $\begin{array}{c}-0.098^{* * *} \\
{[0.036]}\end{array}$ & $\begin{array}{c}-0.094^{* * *} \\
{[0.035]}\end{array}$ \\
\hline $\begin{array}{l}\text { Appointing institution } \\
\text { by_Parliament }\end{array}$ & $\begin{array}{l}-0.171 \\
{[0.125]}\end{array}$ & & & \\
\hline by_President & $\begin{array}{l}-0.131 \\
{[0.125]}\end{array}$ & & & \\
\hline $\begin{array}{l}\text { Job prior to appointment } \\
\text { Executive }\end{array}$ & & $\begin{array}{c}-0.282^{* *} \\
{[0.135]}\end{array}$ & $\begin{array}{c}-0.238^{*} \\
{[0.141]}\end{array}$ & $\begin{array}{c}-0.261^{*} \\
{[0.138]}\end{array}$ \\
\hline Parliamentary & & $\begin{array}{l}-0.116 \\
{[0.145]}\end{array}$ & $\begin{array}{l}-0.188 \\
{[0.153]}\end{array}$ & $\begin{array}{l}-0.098 \\
{[0.147]}\end{array}$ \\
\hline Scholar & & $\begin{array}{l}-0.022 \\
{[0.143]}\end{array}$ & $\begin{array}{l}-0.025 \\
{[0.149]}\end{array}$ & $\begin{array}{l}-0.034 \\
{[0.144]}\end{array}$ \\
\hline $\begin{array}{l}\text { Chief Justice } \\
\text { CJ2_MohMahfudMD }\end{array}$ & & & $\begin{array}{l}0.315^{*} \\
{[0.171]}\end{array}$ & \\
\hline CJ4_HamdanZoelva & & & $\begin{array}{c}0.683^{* *} \\
{[0.340]}\end{array}$ & \\
\hline CJ5_AriefHidayat & & & $\begin{array}{l}-0.155 \\
{[0.144]}\end{array}$ & \\
\hline $\begin{array}{l}\text { Generation } \\
\quad \text { Post_Generation_1 }\end{array}$ & & & & $\begin{array}{c}0.091 \\
{[0.115]}\end{array}$ \\
\hline$N$ & 710 & 710 & 665 & 710 \\
\hline
\end{tabular}

Notes: The dummy variables take one if a justice corresponds to the specified category, zero otherwise. For each classification of dummy variables, the benchmark category is explained in the text. 


\subsubsection{Model-1: Baseline Regression}

The findings reported in Table 5 are broadly in line with findings in the literature. The coefficient of Remaining Tenure of President has the expected negative sign and is statistically significant at the $1 \%$ level. That means the closer the end of the administration, the more likely that justices will vote against it. Similarly, the coefficient for Remaining Tenure as Justice is negative and significant at the $5 \%$ level, suggesting that the closer justices get to retirement, the more likely they are to vote against the administration. These findings are broadly in line with reported strategic behaviour (including strategic defection). Perhaps most interesting is the fact that none of the appointing pathways is statistically significant, though the direction differs. In other words, it does not matter what institution appointed the judge, though those appointed by parliament and by president are slightly more likely than career judges to vote with the government.

\subsubsection{Model-2: Does Work Background Matter?}

Model 2 replaces information about the appointing institution with previous work background in the estimation. Interesting here that, although the direction is negative, only executive background is statistically significant at the $5 \%$ level, which means that justices who before their appointment had worked for the executive were more likely to vote with the current government.

\subsubsection{Model-3: Does the Chief Justice Influence Decisions?}

Model 3 adds a set of new variables to Model 2 to test for differences in judicial behaviour of the bench under different Chief Justices. For all four high-profile cases under the tenure of CJ Akil Mochtar (2013), decisions are unanimously against the sitting administration. On the other hand, there is only one case during the tenure of CJ Usman in our sample, and the decision was unanimously for the sitting administration. Since for these 45 individual votes (i.e. 36 observations under CJ Akil Mochtar and 9 under CJ Usman), voting patterns are perfectly predictable by the CJ dummy 
variables, these observations were dropped from the sample dataset. When compared to first CJ Asshiddiqie (2003-2008), the benches under the tenure of CJs Mahfud (2008-2013) and Zoelva (2013-2015) were more likely to vote against the sitting government (unlike under Arief Hidayat, 2015-2018), and their effects are statistically significant.

\subsubsection{Model-4: Generational Differences?}

Finally, Model 4 tests for the effects of generational cohorts on the bench. Although the coefficients are not statistically significant, justices after the first generation were more likely to vote against the sitting government.

Taken together our regression results only partly confirm widely held perceptions of the behaviour of Indonesian Constitutional Court justices. While we present evidence for strategic behaviour (if not defection) of justices toward the end of a presidential term, and closer to a justice's retirement, we do not find any evidence for differences in judicial behaviour by appointment track, generation, or work background (except for justices from the executive branch). In short, in ruling on the $8 \mathrm{o}$ high-profile political cases in our sample, the voting behaviour of the justices may have been more independent than academics and the public are willing to credit.

\section{CONCLUSION}

The Constitutional Court of Indonesia makes for a fascinating study of judicial behaviour. Often considered perhaps the most activist court in the region, in the last fifteen years the MK has nevertheless earned considerable acclaim within Indonesia's highly dysfunctional legal system. When adjudicating highly charged political matters, it has survived many challenges from within and outside, even as it limited its decision-making in some ways and radically expanded it in others. However, some decisions, and above all corruption scandals, have heightened public concerns and raised a number of questions about its competence, if not impartiality, in politically charged cases..$^{22}$

\footnotetext{
Stefanus Hendrianto and Fritz Siregar, "Developments in Indonesian Constitutional Law: The Year 2016 in Review," in The 1.CONnect-Clough Center 2016 Global Review of Constitutional Law (August 3, 2017), ed. Richard Albert, et al. (Boston: Clough Center for the Study of Constitutional Democracy, 2017).
} 
Taking widespread public and academic concerns as a starting point, this paper offers one of the first empirical accounts of the MK's judicial behaviour in high-profile political cases. Such megapolitical cases are particular suitable for this type of investigation; it is reasonable to assume that strategic behaviour and attitudinal positions come to the fore given the nature and uncertain legal basis of many of the cases. It is our hope that our findings, while certainly no replacement for legal-interpretivist scholarship, offer a much-needed empirically grounded, and ultimately more nuanced, perspective on the performance of the MK in its first 15 years.

In our carefully selected sample, we found little evidence to support some of the most common claims. For instance, while it is true that there is less dissent among justices on the bench over time, it is not clear that the court is deciding less often against government than previously. And while there is evidence of strategic behaviour of justices as the ending of their own terms and that of a president approach, there is little statistical evidence that judicial behaviour has been affected by work background (except for those coming from the executive branch), appointment track or generation. What this suggests is that despite an increasingly politicised nomination process, justices seem to retain more independence than the public seems to perceive - their personal characteristics do not seem to influence the pattern of votes for and against the government.

There is much room for speculation on why this might be. As shown in the diversity and stability on the bench, despite obvious shortcomings, clearly the mixed appointment process has been able to limit the ability of the executive to stack the court as has happened in the Philippines ${ }^{53}$ and other authoritarian regimes in the region. Paradoxically, the competitive clientelist party system while perhaps partly to blame for declining quality in justice selection processes - has also ensured that nomination has remained competitive and is relatively

53 Björn Dressel and Tomoo Inove, "Informal Networks and Judicial Decisions: Insights from the Philippines Supreme Court, 1986-2015," International Political Science Review 39, no. 1 (2018): 616-633. 
transparent to civil society 54 - unlike what has happened in Thailand, where the military regime has gradually gained control over not only nominations to the Constitutional Court but also ultimately over its decision-making process. 55 Compared to such neighbours, the MK seems to be doing rather well.

To be sure, given developments in the region the situation can change quickly; and the judiciary remains vulnerable to attempts to politicize the courts. ${ }^{6}$ Recent corruption scandals in particular illustrate that no matter what institutional safeguards are in place, courts in the region remain deeply enmeshed in clientelist-political structures, including informal practices of obligation and loyalty that might affect the work behaviour of justices on even the highest courts. ${ }^{57}$ These factors, while often hard to grasp empirically, deserve more scholarly attention, ${ }^{5}$ and certainly need to become part of a broader empirical research agenda on courts throughout the Global South. 59

The Constitutional Court of the Republic of Indonesia surely deserves continuing attention. How it exercises its role and guards its powers in years to come will be crucial to how the rule of law and judicial practice evolve not only in Indonesia but throughout a region confronted by consistent challenges to rule-based practice. ${ }^{60}$ Though not always perfect, the MK has certainly done well considering not only the regional context but also the institutional environment in which it operates. It is our hope that this study helps capture its remarkable achievement, and provides a much-needed evidential benchmark for continuing critical evaluation.

\footnotetext{
Faiz, "A Critical Analysis of Judicial Appointment Process and Tenure of Constitutional Justice in Indonesia." 55 Dressel and Tonsakulrungruang, "Coloured Judgement? The Work of the Thai Constitutional Court, 1998-2016." 56 Björn Dressel, "Governance, Courts and Politics in Asia," Journal of Contemporary Asia 44, no. 2 (2014): 259-78. 57 Björn Dressel, "The Informal Dimension of Constitutional Politics in Asia: Insights from the Philippines and Indonesia," in Constitutional Courts in Asia, ed. Albert H.Y. Chen and Andrew Harding (Cambridge: Cambridge University Press., 2018), 60-86.

58 Roux, The Politico-Legal Dynamics of Judicial Review: A Comparative Analysis.

59 Dressel, Sanchez Urribarri, and Stroh, "Courts and Informal Networks: Towards a Relational Perspective on Judicial Politics beyond Western Democracies."

6o Melissa Curley, Björn Dressel, and Stephen McCarthy, "Competing Visions of the Rule of Law in Southeast Asia: Power, Rhetoric and Governance," Asian Studies Review 42, no. 2 (2018): 192-209.
} 


\section{Appendix: List of Megapolitical Cases, 2004-2018}

\begin{tabular}{|c|c|c|c|}
\hline Case ID & Case Number & Date of Decision & $\begin{array}{c}\text { Case Type } \\
\end{array}$ \\
\hline 1 & 011/PUU-I/2003 & $2004 / 2 / 24$ & Bill of Rights/Liberties \\
\hline 2 & o62/PHPU.B-II/2004 & $2004 / 8 / 9$ & Election (Political Contest) \\
\hline 3 & 18/PUU-I/2003 & $2004 / 9 / 11$ & Separation of Powers \\
\hline 4 & 001/PUU-I/2003 & $2004 / 12 / 15$ & Economic \\
\hline 5 & 065/PUU-II/2004 & $2005 / 3 / 3$ & Bill of Rights/Liberties \\
\hline 6 & o66/PUU-II/2004 & $2005 / 4 / 12$ & Separation of Powers \\
\hline 7 & 012/PUU-III/2005 & $2005 / 10 / 19$ & Bill of Rights/Liberties \\
\hline 8 & 026/PUU-III/2005 & $2006 / 3 / 22$ & Bill of Rights/Liberties \\
\hline 9 & 13/PUU-IV/2006 & $2006 / 12 / 6$ & Bill of Rights/Liberties \\
\hline 10 & 006/PUU-IV/2006 & $2006 / 12 / 7$ & Bill of Rights/Liberties \\
\hline 11 & 16/PUU-IV/2006 & $2006 / 12 / 19$ & Separation of Powers \\
\hline 12 & 026/PUU-III/2005 & $2007 / 5 / 1$ & Bill of Rights/Liberties \\
\hline 13 & 6/PUU-V/2007 & $2007 / 7 / 17$ & Bill of Rights/Liberties \\
\hline 14 & 5/PUU-V/2007 & $2007 / 7 / 23$ & Bill of Rights/Liberties \\
\hline 15 & 2-3/PUU-V/2007 & $2007 / 10 / 30$ & Bill of Rights/Liberties \\
\hline 16 & 18/PUU-V/2007 & $2008 / 2 / 21$ & Separation of Powers \\
\hline 17 & 10/PUU-VI/2008 & $2008 / 7 / 1$ & Election (Political Contest) \\
\hline 18 & 13/PUU-VI/2008 & $2008 / 8 / 11$ & Bill of Rights/Liberties \\
\hline 19 & 41/PHPU.D-VI/2008 & $2008 / 12 / 2$ & Election (Political Contest) \\
\hline 20 & 22-24/PUU-VI/2008 & $2008 / 12 / 23$ & Bill of Rights/Liberties \\
\hline 21 & 57/PHPU.D-VI/2008 & $2009 / 1 / 8$ & Election (Political Contest) \\
\hline 22 & 4/PUU-VII/2009 & $2009 / 3 / 24$ & Election (Political Contest) \\
\hline 23 & 9/PUU-VII/2009 & $2009 / 3 / 25$ & Election (Political Contest) \\
\hline 24 & 98/PUU-VII/2009 & $2009 / 7 / 2$ & Election (Political Contest) \\
\hline 25 & 99/PUU-VII/2009 & $2009 / 7 / 2$ & Election (Political Contest) \\
\hline 26 & 102/PUU-VII/2009 & $2009 / 7 / 6$ & Election (Political Contest) \\
\hline 27 & 108-109/PHPU.B-VII/2009 & $2009 / 8 / 12$ & Election (Political Contest) \\
\hline 28 & 117/PUU-VII/2009 & $2009 / 9 / 30$ & Separation of Powers \\
\hline 29 & 133/PUU-VII/2009 & $2009 / 11 / 25$ & Separation of Powers \\
\hline 30 & 10-17-23/PUU-VII/2009 & $2010 / 3 / 25$ & Bill of Rights/Liberties \\
\hline 31 & 11/PUU-VII/2009 & $2010 / 3 / 31$ & Executive Prerogatives \\
\hline 32 & 140/PUU-VII/2009 & $2010 / 4 / 19$ & Bill of Rights/Liberties \\
\hline 33 & 49/PUU-VIII/2010 & $2010 / 9 / 22$ & Executive Prerogatives \\
\hline 34 & 23/PUU-VIII/2010 & $2011 / 1 / 12$ & Separation of Powers \\
\hline 35 & 79/PUU-IX/2011 & $2011 / 6 / 5$ & Executive Prerogatives \\
\hline 36 & 5/PUU-IX/2011 & $2011 / 6 / 20$ & Separation of Powers \\
\hline 37 & 15/PUU-IX/2011 & $2011 / 7 / 4$ & Election (Political Contest) \\
\hline 38 & 55/PUU-VIII/2010 & 2011/9/19 & Bill of Rights/Liberties \\
\hline 39 & 49/PUU-IX/2011 & $2011 / 10 / 18$ & Separation of Powers \\
\hline 40 & 46/PUU-VIII/2010 & $2012 / 2 / 17$ & Bill of Rights/Liberties \\
\hline
\end{tabular}




\begin{tabular}{|c|c|c|c|}
\hline Case ID & Case Number & Date of Decision & Case Type \\
\hline 41 & $2 / \mathrm{SKLN}-\mathrm{X} / 2 \mathrm{O12}$ & $2012 / 7 / 31$ & Executive Prerogatives \\
\hline 42 & 52/PUU-X/2012 & $2012 / 8 / 29$ & Election (Political Contest) \\
\hline 43 & 36/PUU-X/2012 & $2012 / 11 / 13$ & Economic \\
\hline 44 & 10/PUU-X/2012 & $2012 / 11 / 22$ & Separation of Powers \\
\hline 45 & 5/PUU-X/2012 & $2013 / 1 / 8$ & Executive Prerogatives \\
\hline 46 & 114/PUU-X/201 & $22013 / 3 / 28$ & Bill of Rights/Liberties \\
\hline 47 & 35/PUU-X/2012 & $2013 / 5 / 16$ & Bill of Rights/Liberties \\
\hline 48 & 39/PUU-XI/2013 & $2013 / 7 / 31$ & Election (Political Contest) \\
\hline 49 & 14/PUU-XI/2013 & $2014 / 1 / 23$ & Election (Political Contest) \\
\hline 50 & 1-2/PUU-XII/2O14 & $2014 / 2 / 13$ & Separation of Powers \\
\hline 51 & 34/PUU-XI/2013 & $2014 / 3 / 6$ & Bill of Rights/Liberties \\
\hline 52 & 20/PUU-XI/2013 & $2014 / 3 / 12$ & Bill of Rights/Liberties \\
\hline 53 & 83/PUU-XI/2013 & $2014 / 4 / 26$ & Bill of Rights/Liberties \\
\hline 54 & 97/PUU-XI/2013 & $2014 / 5 / 19$ & Separation of Powers \\
\hline 55 & 35/PUU-XI/2013 & $2014 / 5 / 22$ & Separation of Powers \\
\hline 56 & 50/PUU-XII/2014 & $2014 / 7 / 3$ & Election (Political Contest) \\
\hline 57 & 76/PUU-XII/2014 & $2014 / 11 / 21$ & Separation of Powers \\
\hline 58 & 18/PUU-XII/2014 & $2015 / 1 / 21$ & Other \\
\hline 59 & 74/PUU-XII/2014 & $2015 / 6 / 18$ & Bill of Rights/Liberties \\
\hline 60 & 85/PUU-XI/2013 & $2015 / 2 / 18$ & Economic \\
\hline 61 & 21/PUU-XII/2014 & $2015 / 4 / 28$ & Bill of Rights/Liberties \\
\hline 62 & 68/PUU-XII/2014 & $2015 / 6 / 18$ & Bill of Rights/Liberties \\
\hline 63 & 33/PUU-XIII/2015 & $2015 / 7 / 8$ & Election (Political Contest) \\
\hline 64 & 42/PUU-XIII/2015 & $2015 / 7 / 9$ & Election (Political Contest) \\
\hline 65 & 46/PUU-XIII/2015 & $2015 / 7 / 19$ & Election (Political Contest) \\
\hline 66 & 100/PUU-XIII/2015 & $2015 / 9 / 29$ & Election (Political Contest) \\
\hline 67 & 6/PUU/XIV/2016 & $2016 / 8 / 4$ & Separation of Powers \\
\hline 68 & 51/PUU-XIV/201 & $2016 / 8 / 23$ & Election (Political Contest) \\
\hline 69 & 21/PUU-XIV/2016 & $2016 / 9 / 7$ & Bill of Rights/Liberties \\
\hline 70 & 20/PUU-XIV/2016 & $2016 / 9 / 7$ & Bill of Rights/Liberties \\
\hline 71 & 63/PUU/XIV/2016 & $2016 / 12 / 14$ & Economic \\
\hline 72 & 59/PUU/XIV/2016 & $2016 / 12 / 14$ & Economic \\
\hline 73 & 58/PUU/XIV/2016 & $2016 / 12 / 14$ & Economic \\
\hline 74 & 57/PUU/XIV/2016 & $2016 / 12 / 14$ & Economic \\
\hline 75 & 49/PUU/XIV/2016 & $2017 / 2 / 21$ & Separation of Powers \\
\hline 76 & 92/PUU/XIV/2016 & $2017 / 7 / 10$ & Separation of Powers \\
\hline 77 & 71/PUU-XIV/2016 & $2017 / 7 / 19$ & Election (Political Contest) \\
\hline 78 & 53/PUU/XIV/2016 & $2017 / 7 / 19$ & Separation of Powers \\
\hline 79 & 53/PUU-XV/2017 & $2018 / 1 / 11$ & Election (Political Contest) \\
\hline 80 & 16/PUU-XVI/2018 & $2018 / 6 / 28$ & Separation of Powers \\
\hline
\end{tabular}




\section{BIBLIOGRAPHY}

Bailey, Michael A., and Forrest Maltzman. The Constrained Court: Law, Politics and the Decisions Justices Make. Princeton: Princeton University Press, 2011.

Baum, Lawrence. Judges and Their Audiences: A Perspective on Judicial Behavior. Princeton: Princeton University Press, 2006.

_—_. "What Judges: Judges' Goals and Judicial Behavior." Political Research Quarterly 47, no. 3 (1994): 749-68.

Bisariyadi. "The Application of Legal Construction in the Rulings of the Constitutional Court." MIMBAR HUKUM 29, no. 1 (2017): 135-49.

_- _. "A Typical Rulings of the Indonesian Constitutional Court." Hasanuddin Law Review 2, no. 2 (2016): 225-40.

Butt, Simon. "The Constitutional Court's Decision in the Dispute between the Supreme Court and the Judicial Commission: Banishing Judicial Accountability?". In Indonesia Democracy and the Promise of Good Governance, edited by Ross H. McLeod and Andrew MacIntyre. 178-99. Singapore: Instititute of South East Asian Studies, 2007.

-_- The Constitutional Court and Democracy in Indonesia. Leiden: Brill Nijhoff, 2015.

-——. "Indonesia's Constitutional Court: A Reform over-Achiever?". Inside Indonesia 87, no. July-September (2006): 10-11.

- _- "Indonesia's Constitutional Court: Conservative Activist or Strategic Operator?". In The Judicialization of Politics in Asia, edited by Björn Dressel. Abingdon; New York: Routledge, 2012.

-_- "Indonesian Constitutional Court Decisions in Regional Head Electoral Disputes." CDI Policy Papers on Political Governance., Australian National University, 1-37, 2013.

Curley, Melissa, Björn Dressel, and Stephen McCarthy. "Competing Visions of the Rule of Law in Southeast Asia: Power, Rhetoric and Governance." Asian Studies Review 42, no. 2 (2018/04/o3 2018): 192-209. 
Desierto, Desiree A. "Judicial Independence: Evidence from the Philippine Supreme Court (1970-2003)." In The Political Economy of Governance, edited by Norman Schofield and Gonzalo Caballero. 41-57. Cham: Springer International Publishing, 2015.

Dressel, Björn. "Governance, Courts and Politics in Asia." Journal of Contemporary Asia 44, no. 2 (2014/04/03 2014): 259-78.

—_- "The Informal Dimension of Constitutional Politics in Asia: Insights from the Philippines and Indonesia." In Constitutional Courts in Asia, edited by Albert H.Y. Chen and Andrew Harding. 6o-86. Cambridge: Cambridge University Press., 2018.

- - - The Judicialization of Politics in Asia. Abingdon and New York: Routledge, 2012.

Dressel, Björn, and Tomoo Inoue. "Informal Networks and Judicial Decisions: Insights from the Philippines Supreme Court, 1986-2015." International Political Science Review $\backslash$.

Dressel, Björn, Raul Sanchez Urribarri, and Alexander Stroh. "Courts and Informal Networks: Towards a Relational Perspective on Judicial Politics Beyond Western Democracies." International Political Science Review 39, no. 5 (2018): 573-584.

- ——. "The Informal Dimension of Judicial Politics: A Relational Perspective." Annual Review of Law and Social Science 13 (2017): 413-30.

Dressel, Björn, and Khemthong Tonsakulrungruang. "Coloured Judgement? The Work of the Thai Constitutional Court, 1998-2016." Journal of Contemporary Asia early print (13 June 2018).

Epstein, Lee, and Jack Knight. The Choices Justices Make. Washington, DC: CQ Press, 1998.

Faiz, Pan Mohamad. "A Critical Analysis of Judicial Appointment Process and Tenure of Constitutional Justice in Indonesia." Hasanuddin Law Review 2, no. 2 (2016): 152-68. 
Hendrianto. "Institutional Choice and the New Indonesian Constitutional Court." In New Courts in Asia, edited by Andrew Harding and Penelope Nicholson, 158-77. Oxon and New York: Routledge, 2010.

Hendrianto, Stefanus. "Convergence or Borrowing: Standing in the Indonesian Constitutional Court." Constitutional Review 1, no. 1 (2015).

- - " "The Indonesian Constitutional Court and the Crisis of the 2019 Presidential Election.” In, I-CONnect Blog no. Sept. 19, 2018 (2018). http:// www.iconnectblog.com/2018/og/the-indonesian-constitutional-court-andthe-crisis-of-the-2019-presidential-election/.

- - L Law and Politics of Constitutional Courts: Indonesia and the Search for Judicial Heroes. New York: Routledge, 2018.

-_—. "The Rise and Fall of Heroic Chief Justices: Constitutional Politics and Judicial Leadership in Indonesia." Washington International Law Journal 25, no. 3 (2016).

Hendrianto, Stefanus, and Fritz Siregar. "Developments in Indonesian Constitutional Law: The Year 2016 in Review." In The I.Connect-Clough Center 2016 Global Review of Constitutional Law (August 3, 2017), edited by Richard Albert, David Landau, Pietro Faraguna and Simon Drugda. Boston: Clough Center for the Study of Constitutional Democracy, 2017.

Horowitz, Donald. Constitutional Change and Democracy in Indonesia. Cambridge and New York: Cambridge University Press, 2013.

Lev, Daniel S. "State and Law Reform in Indonesia." In Law Reform in Developing and Transitional States, edited by Timothy Lindsey. 236-67. London and New York: Routledge, 2007.

Mietzner, Marcus. "Political Conflict and Democratic Consolidation in Indonesia: The Role of the Constitutional Court." Journal of East Asian Studies 10, no. 3 (2010): 397-424.

Nardi, Dominic. "Demand-Side Constitutionalism: How Indonesian NGOs Set the Constitutional Court's Agenda and Inform the Justices." Centre for Indonesian Law , Islamic Society, Policy Paper., 2018. 
Ramseyer, Mark J. "The Puzzling (in)Dependence of Courts: A Comparative Approach." Journal of Legal Studies 23 (1994): 721-47.

Rios-Figuero, Julio, and Jeffrey K. Staton. "An Evaluation of Cross-National Measures of Judicial Independence." The Journal of Law, Economics, and Organizations 30, no. 1 (2009): 104-37.

Roux, Theunis. "American Ideas Abroad: Comparatiove Implications of Us Supreme Court Decision-Making Models." I Con 13, no. 1 (2015): 90-118.

- - - The Politico-Legal Dynamics of Judicial Review: A Comparative Analysis. Comparative Constitutional Law and Policy. Cambridge: Cambridge University Press, 2018. DOI: 10.1017/9781108340977.

Roux, Theunis, and Fritz Edward Siregar. "Trajectories of Curial Power: The Rise, Fall and Partial Rehabilitation of the Indonesian Constitutional Court." Australian Journal of Asian Law 16, no. 2 (2016): 1-21.

Russel, Peter H. “Towards a General Theory of Judicial Independence." In Judicial Independence in the Age of Democracy. Critical Perspectives from around the World, edited by Peter H. Russel and David M O'Brian. 1-24. Charlottsville and London: University of Virginia Press, 2001.

Segal, Jeffrey A., and Harold J. Spaeth. The Supreme Court and the Attitudinal Model. New York: Cambridge University Press, 1993.

-_- The Supreme Court and the Attitudinal Model Revisited. Cambridge: Cambridge University Press, 2002.

Shapiro, Martin. Courts: A Comparative and Political Analysis. Chicago: Chicago University Press, 1981.

Sieder, Rachel, Line Schjolden, and Alan Angell, eds. The Judicialization of Politics in Latin America. New York and Houndsmills: Palgrave Macmillan, 2005. Spiller, Pablo, and Rafael Gely. "Strategic Judicial Decision-Making." In The Oxford Handbook of Law and Politics, edited by Keith E. Whittington, Daniel R. Kelemen and Gregory A. Caldeira. 35-43. Oxford: Oxford University Press, 2010. 
Siregar, Fritz. "The Political Context of Judicial Review in Indonesia." Indonesia Law Review 2 (2015): 208-37.

Stockmann, Petra. The New Indonesian Constitutional Court: A Study into Its Begining and First Years of Work. Jakarta: Hanns Seidel Foundation, 2007. Tate, Neal C., and Torbjörn Vallinder, eds. The Global Expansion of Judicial Power. New York: New York University Press, 1995. 